\title{
The Spatial Autocorrelation between Precipitation and Vegetation Indices in the Bandar Abbas Basin
}

\author{
Mehran Safa $^{* 1}$, Mirmasoud Kheirkhah Zarkesh ${ }^{2}$, Farid Ejlali ${ }^{3}$, Forough Farsad ${ }^{4}$ \\ ${ }^{1} \mathrm{PhD}$ student in Environment, Science and Research Branch of Islamic Azad University, Tehran, \\ Iran. \\ ${ }^{2}$ Associate Professor, Soil Conservation and Watershed Management Research Institute, Islamic \\ Azad University, Science and Research Branch (Tehran), Iran. \\ ${ }^{3} \mathrm{PhD}$ in Meteorology and Associate Professor, Payame Noor University of Tehran and Islamic \\ Azad University, Science and Research Branch (Tehran), Iran. farid.ejlali@gmail.com \\ ${ }^{4}$ Assistant Professor, Department of Environmental Sciences Islamic Azad University, Science and \\ Research Branch (Tehran), Iran. forough.farsad@ yahoo.com
}

\begin{abstract}
:
This study aimed to investigate the spatial autocorrelation between precipitation and vegetation indices in the Bandar Abbas basin. For this purpose, the vegetation indices of DVI, EVI, IPVI, NDVI, NDWI, RVI,SAVI, TCI, VCI, and VHI were derived from Landsat satellite images over 20 years were studied. Precipitation data corresponding to rain gauge stations was extracted. The Pearson correlation coefficient and the GI * and I indices were used to investigate the relationship between precipitation and spatial auto correlation. Moreover, the Pearson correlation coefficient was used to investigate the relationship between precipitation and vegetation indices, and the GI * and I indices was used to correlate spatial autocorrelation patterns. The results showed that SAVI, VHI, VCI, and NDWI were most correlated with precipitation among the Bandar Abbas basin's vegetation indices, with the SAVI index being more close lycorrelated than the others. However, precipitation had the least impact on the TCI index. The spatial autocorrelation of rainfall with the vegetation indices, except for the IPVI index, had a scattered pattern in the study area's southern and eastern parts. Of the indices studied in terms of spatial pattern, the IPVI and NDWI indices formed a positive spatial correlation pattern with precipitation over a greater spatial range.
\end{abstract}

Keywords: Vegetation indices, spatial autocorrelation pattern, GI * and I indices, Pearson correlation coefficient, Bandar Abbass

\section{Introduction}

In the international approaches to vegetation to estimate agricultural production at regional and national levels is the use of remote sensing technology. According to Carvalho et al, (2008), remotely sensed data is a regular source of information and it is important for the systematic monitoring of the vegetation dynamics. The results of the findings suggest that climate change, especially rainfall reduction and increasing temperatures around the world, has led to the loss of forest cover (Azizi et al. 2015; Thiele et al. 2017). One of the important parts of land cover is Vegetation, which plays a very important role in conserving soil, regulating the atmosphere, and maintaining the stability of the ecological system. (Ding, 2016; Liu and Fu, 2013). Remote sensing serves as an ideal tool for this purpose. The Normalized Difference Vegetation Index (NDVI), derived from Moderate Resolution Imaging Spectroradiometer (MODIS) data, can capture the surface vegetation greenness and coverage (Yengoh et al, 2015), and therefore has been widely used in vegetation dynamics monitoring (Bing et al, 2014; Lin et al, 2020). The satellite Landsat-8 has been equipped with two sensors: The Operational Land Imager (OLI), designed in order to operate in continuity with TM and ETM+; and the Thermal Infrared Sensor (TIRS), which features two bands in the thermal infrared region. The OLI sensor includes enhanced bands due to new linear detector arrays which collect images in a push-broom scanner mode providing a better signal with a high signal-to-noise ratio, compared to the previous whiskbroom scanner-based sensor (Irons et al, 2012). The main differences between OLI and 
previous TM and ETM+ sensors refer not only to the overall image quality but also to the different number of spectral bands, their width and their spatial resolutions (USGS, 2019). In general, in order to access vegetation information, it is possible to combine at least two bands in satellite images and create a composite index called vegetation index. Vegetation indices are widely used as criteria for analyzing land cover changes including vegetation and other factors (Kazeminia 2018). Mokarm et al. (2017) investigated changes in vegetation cover in different seasons using satellite imagery and its relationship with temperature changes. The vegetation indices NDVI, RVI, SS, and VIN were used to examine the study area's vegetation. Regression analysis was used to investigate the relationship between the vegetation indices and temperature. The correlation and linear regression results showed a significant relationship between the vegetation indices and temperature almost in the entire study area (above 90\%). The vegetation indices decreased by increasing temperature. The results also showed that among the vegetation indices, NDVI was more accurate in predicting vegetation cover. Karimi et al. 2020, analyzed the performance of plant indicators in agricultural drought using remote sensing method in the Karkheh basin. For this purpose, used of NDVI, EVI and VCI vegetation indices in agricultural drought identification and analysis. The results showed that the changes of NDVI, EVI and VCI in the studied stations were approximately the same during the statistical period. Then, in order to validation of the results, the vegetation indices with the ZSI index were evaluated. Pearson correlation between mean vegetation indices of NDVI, EVI and VCI with mean ZSI was 0. 766, 0. 725 and 0. 776, respectively, and all vegetation indices with ZSI index are significant at $0.99 \%$ confidence level. As seen, according to the results, the ZSI index confirms the results of NDVI, EVI, and VCI. So, according to the results, there is no conformity of meteorological and agricultural droughts in all years, Therefore, in addition to other precipitation, climate variables should also be considered. The difference vegetation index is used to distinguish between soil and vegetation; however, it does not take into account the effect of atmosphere reflectance or shadows (Naji 2018). VHI is a widely used remote sensing-based drought index designed as the weighted sum of two components: The Vegetation Condition Index (VCI) and the Thermal Condition Index (TCI). The first component characterizes moisture conditions and is typically based on information from the visible and near infra-red windows of the electromagnetic spectrum, whereas the latter characterizes the thermal condition and is based on information from the thermal infra-red window. The Normalized Difference Vegetation Index (NDVI) and LST (or TOA brightness temperature) are commonly used to estimate VCI and TCI, respectively. The optimum weights that are to be attributed to VCI and TCI are usually not known and VHI is typically estimated by assuming equal weights of 0.5 to both components (Virgílio et al, 2018). The NDWI, based on the combination of the green band with NIR or SWIR, is a good indicator for vegetation liquid water content and in the same time is less sensitive to atmospheric scattering effects than NDVI (Gao, 1996). Its usefulness for drought monitoring and early warning has been demonstrated in different studies (Gu et al, 2007; Ceccato et al, 2002). The EVI (Enhanced Vegetation Index) represents an improvement of NDVI, showing a reduced saturation in high vegetation cover regions, a reduction in atmospheric influences and a de-coupling of the canopy background signal (Xiao et al, 2006). These improvements are based on the introduction of the blue band to reduce the effects of the atmospheric aerosols in the red band, and on some correction coefficients to reduce the effect of soil reflectance. According to these differences, the NDVI is more sensitive to the chlorophyll content, whilst the EVI is more sensitive to the structural characteristics of the vegetation cover (Solano et al, 2010). Thus, it has been widely used for Land Cover and Land Use/Land Cover Change detection (Wardlow et al, 2007), for the evaluation of vegetation bio-physical parameterization (Houborg et al, 2007), phenology (Ahl et al, 2006), evapotranspiration (Nagler et al, 2005), biodiversity assessment (Waring et al, 2006), and gross primary production (Sims et al, 2008). The SAVI (Soil-Adjusted Vegetation Index), proposed by Huete (Huete et al, 1996) reduces the effects of soil on vegetation reflectance (Miura et al, 2000). The DVI index ranges from 1 to 0 for marine and non-vegetated areas and from 0 to 0.07 for unhealthy vegetation and from 0.07 to higher value (often 1) for areas with healthy plants (Vani, Mandla 2017). SAVI index solves this problem in the NDVI index. This index uses a factor called L to moderate the effect of background soil. The amplitude of changes in the SAVI index for aquatic and non-vegetated areas is the same as for the NDVI index from 1 to 0 , for areas with unhealthy vegetation from 0 to 0.15 and for areas with healthy vegetation from 0.15 to 1 ; by the way, L factor is set at 0.5 (Vani, Mandla 2017). This parameter reduces the field-effect index and reflects a lower plant cover percentage (Ghavidel et al, 2021). The normalized difference index vegetation indicates how many green leaves exist (Robinson et al. 2017). The NDVI index ranges for aquatic or nonvegetated areas (mountains or boulders) from -1 to 0 , for areas with unhealthy or contaminated vegetation 
from 0 to 0.33 and for areas with healthy plants from 0.33 up to 1 (GIS Geography 2019). The main objectives of this study analyzes vegetation dynamics and their responses to precipitation in time series of NDVI derived from Landsat TM, ETM +, and OLI satellite data from 1998 to 2017. It has two major objectives: (1) analyze the temporal variation and spatial heterogeneity of precipitation in the Bandar abbass from 1998 to 2017; (2) Quantitatively analyze the response of vegetation to precipitation and the difference in vegetation response.

\section{Data and methodology}

\section{Study area}

The Bandar Abbas area with an area of $1405.5 \mathrm{~km} 2$ is the Hormozgan capital city, (Figure 1). Characterized by a typically arid continental monsoon climate, Rainfall distribution in the study area is not uniform and is a schema with $152.9 \mathrm{~mm}$ of average annual rainfall data, that more than $77 \%$ occurs in the rainy season (autumn and winter) causing severe soil erosion. the location of the case study showed in figure 1.

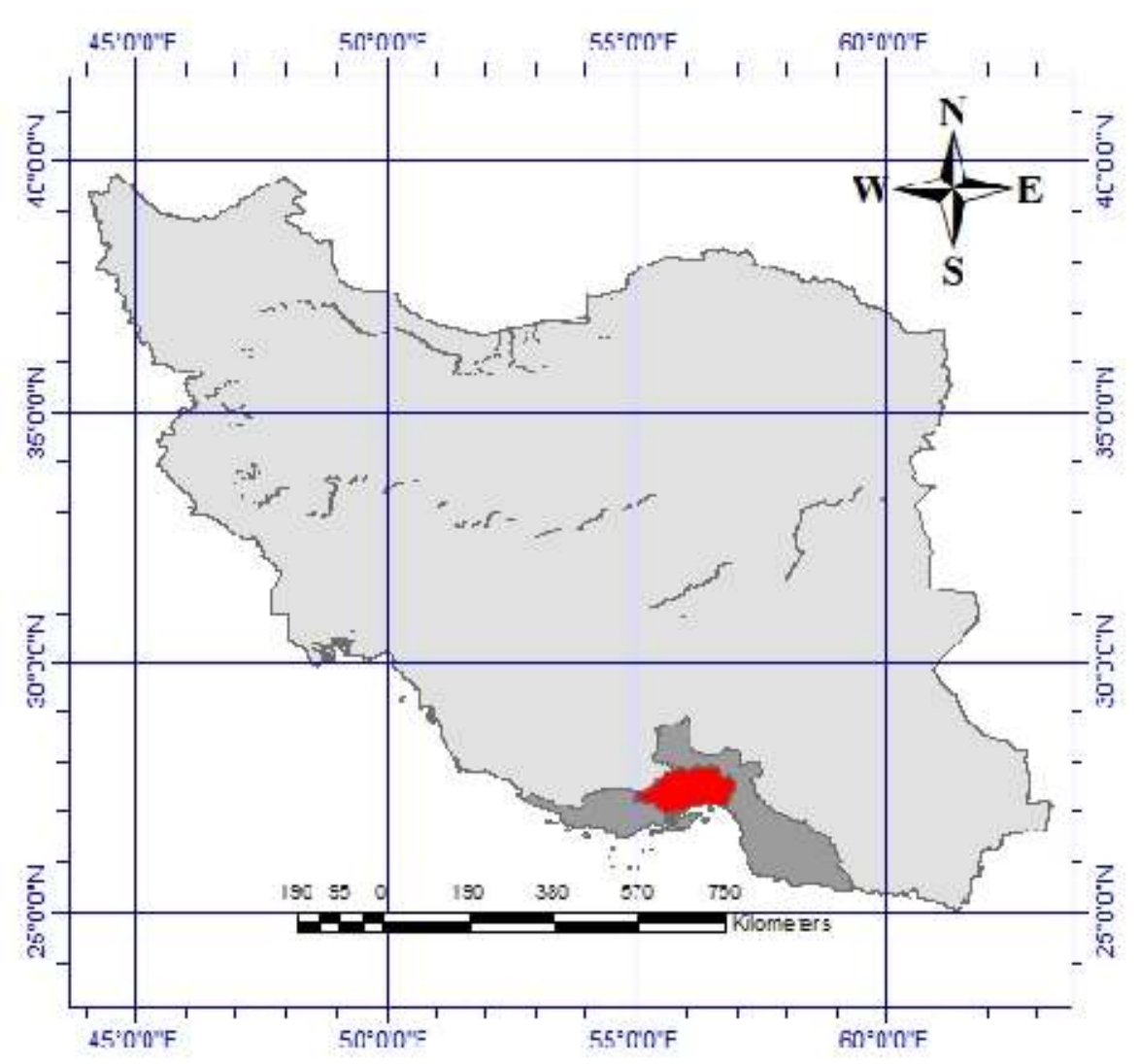

Fig 1: View of study area in Iran country and Hormozgan province

\section{Methodology}

In this study, to prepare satellite images from regions covered, the Earth Explorer (https://earthexplorer.usgs.gov/) and the images taken from Landsat 8 satellite with a spatial resolution of less than $30 \mathrm{~m}$ were used. In this study, images taken from 1998 to 2017 were used. It is reported that with the transformation of grey to high atmosphere reflectance, the quality level for water and soil classification could be promoted dramatically (Maglione et al. 2013). In this study, the radiometric detection of the Land sat 8 satellite was performed by converting the grey level of each image pixel to high atmosphere reflectance values using metadata. To determine the mean value of each index at the area level, the histogram was used. Also, the area for each class was calculated using pixel number multiplication. Finally, we used the ArcMap software (https://desktop .arcgis.com /en/ arcmap/) to get the job done. (Safari et al. 2018). Hence in this study, used Rainfall data for 30 rain gauge stations and Landsat TM, ETM +, and OLI satellite data from 1998 to 
2017 to investigate the spatial autocorrelation relationship between precipitation and vegetation indices in the Bandar Abbas-Sadiq basin.

\section{Vegetation Indices}

The ETM+ and OLI derived vegetation indices used for the comparative analysis are reported in Table 1. Therefore, extracted the vegetation indices DVI, EVI, IPVI, NDVI, NDWI, RVI, SAVI, TCI, VCI, and VHI corresponding to the 30 rain gauge stations over 20 years from 1998 to 2017. In this study, according to the necessity of studying the vegetation cover for determining the of the studied areas, the following indices difference vegetation index (DVI), normalized difference vegetation index (NDVI), soil adjusted vegetation index (SAVI), Enhanced Vegetation Index (EVI), and plant health index (PHI) were used. Table 1 gives the general explanation of these indices. These indices have their own biologically motivated definitions, for example NDVI for a given pixel always results in a number that ranges from -1 to +1 ; in which no green leaves give a value close to zero. A zero means no vegetation, however a high NDVI value, $+1(0.8-0.9)$ indicates healthy vegetation and a low NDVI value, -1 indicates less or no vegetation. These indices would help to develop a method for measuring plants in different conditions (Ghavidel et al, 2021).

Table 1: The vegetation indices used in the study

\begin{tabular}{|c|c|c|c|c|}
\hline $\begin{array}{l}\text { Vegetation } \\
\text { index name }\end{array}$ & $\begin{array}{l}\text { Abbrevi } \\
\text { ation }\end{array}$ & Presenter & $\begin{array}{l}\text { The year of } \\
\text { introduction }\end{array}$ & Formula \\
\hline $\begin{array}{l}\text { Normalized } \\
\text { Difference } \\
\text { Vegetation } \\
\text { Index }\end{array}$ & NDVI & Rouse & 1972 & $N D V I=\frac{N I R-R e d}{N I R+R e d}$ \\
\hline $\begin{array}{l}\text { Enhanced } \\
\text { Vegetation } \\
\text { Index }\end{array}$ & EVI & $\begin{array}{l}\text { Huete and } \\
\text { Justice }\end{array}$ & 1999 & 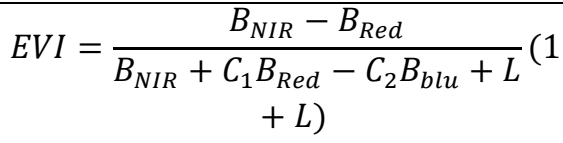 \\
\hline $\begin{array}{l}\text { Soil Adjusted } \\
\text { Vegetation } \\
\text { Index }\end{array}$ & SAVI & Huete & 1988 & $S A V I=\frac{N I R-R}{N I R+R+L}(1+L)$ \\
\hline $\begin{array}{l}\text { Ratio } \\
\text { Vegetation } \\
\text { Index }\end{array}$ & RVI & Jordan & 1969 & $R V I=\frac{N I R}{R e d}$ \\
\hline $\begin{array}{l}\text { Normalized } \\
\text { Difference } \\
\text { Water Index }\end{array}$ & NDWI & $\begin{array}{l}\text { Gao and Bo- } \\
\text { Cai }\end{array}$ & 1996 & $N D W I=\frac{N I R-S W I R}{N I R+S W I R}$ \\
\hline $\begin{array}{l}\text { Difference } \\
\text { Vegetation } \\
\text { Index }\end{array}$ & DVI & $\begin{array}{l}\text { Richardson and } \\
\text { Everitt }\end{array}$ & 1992 & $D V I=N I R-R E D$ \\
\hline $\begin{array}{c}\text { Infrared } \\
\text { Percentage } \\
\text { Vegetation } \\
\text { Index }\end{array}$ & IPVI & Crippen & 1990 & $I P V I=\frac{(N D V I+1)}{2}=\frac{N I R}{(N I R+R E D}$ \\
\hline $\begin{array}{l}\text { Temperature } \\
\text { Condition } \\
\text { Index }\end{array}$ & TCI & Kogan & 1997 & $T C I_{j}=\frac{T_{\max }-T_{j}}{T_{\max }-T_{\min }} \times 100$ \\
\hline $\begin{array}{l}\text { Vegetation } \\
\text { Condition } \\
\text { Index }\end{array}$ & VCI & Kogan & 1997 & $V C I=\frac{\left(N D V I_{j}-N D V I_{\min }\right)}{\left(N D V I_{\max }-N D V I_{\min }\right)} \times 100$ \\
\hline $\begin{array}{l}\text { Vegetation } \\
\text { Health Index }\end{array}$ & VHI & Kogan & 1997 & $V H I=\frac{1}{2} V C I+\frac{1}{2} T C I$ \\
\hline
\end{tabular}


After preparing a database of precipitation and vegetation indices, the Pearson correlation coefficient was used to evaluate the degree of correlation (invariance), and the Hotspot Spatial Autocorrelation Index (GI *) and the Moran's Index (I) were used to correlate the spatial pattern. The GI * index measures the degree of correlation resulting from the concentration of well-proportioned points (or the area by well-proportioned points) and all well-proportioned points within the radius $\mathrm{d}$ of the turning point. This index is an appropriate criterion to assess the dependence of points. In 1992, Gates and Ord proposed the G and $G^{*}$ statistics to measure spatial correlation in multiple states. The Gi (d) statistic is calculated using the following equation (Gates \& Ord, 1995):

$$
G_{i}(d)=\frac{\sum_{j} w_{i j}(d) x_{j}}{\sum_{j} x_{j}} j \neq i
$$

Where $\mathrm{w}_{\mathrm{ij}}(\mathrm{d})$ is proportional to the spatial weight matrix of one or zero. The expression will be one if the point is within the interval distance (d) intended for the point $i$. In the $G$ index, the relation of each point to itself is considered zero. The sum of weights is written as follows:

$$
W_{i}=\sum_{j \neq i} w_{i j}(d)
$$

The sigma counter operator in the equation (1) is the sum of all $x_{j}$ within the radius $d$ of the point $i$. It should be noted that $x_{i}$ itself is not considered. In the denominator, the resulting fraction is the sum of all $x_{j}$, regardless of $\mathrm{x}_{\mathrm{i}}$. The mean and diffraction for the point $\mathrm{i}$ will be obtained using the following equations:

$$
\bar{x}_{i}=\frac{\sum_{j} x_{i}}{(n-1)} \quad s^{2}(i)=\frac{\sum_{j} x^{2}{ }_{j}}{(n-1)}-[\bar{x}(i)]^{2}
$$

Moreover, Gi diffraction can be obtained using the following equation:

$$
\operatorname{Var}\left(G_{i}\right)=\frac{W_{i}\left(n-1-W_{i}\right)}{(n-1)^{2}(n-2)}\left[\frac{s(i)}{\bar{x}(i)}\right]^{2}
$$

$\mathrm{G}$ and $\mathrm{G} *$ values are standardized using the statistical method $\mathrm{W}_{\mathrm{i}} /(\mathrm{n}-1)$ and its second root diffraction calculation.

$$
G_{i}(d)=\frac{\sum_{j} w_{i j}(d) x_{j}-W_{i} \bar{x}(i)}{s(i)\left\{\left[\left((n-1) S_{1 i}\right)-W_{i}^{2}\right] /(n-2)\right\}^{\frac{1}{2}}}, j \neq i
$$

If we consider the weight of the point $\mathrm{i}\left(\mathrm{w}_{\mathrm{ii}} \neq 0\right)$, the standardized $\mathrm{G} *$ statistic will be obtained using the following equation (Fischer and Wang, 2011):

$$
G_{i}^{*}(d)=\frac{\sum_{j} w_{i j}(d) x_{j}-W_{i}^{*} \bar{x}}{s(i)\left\{\left[\left(n S_{1 i}^{*}\right)-W_{i}^{* 2}\right] /(n-2)\right\}^{\frac{1}{2}}}, j=i
$$

In the equations (6) and (7), $W_{i}^{*}=W_{i}+w_{i i}$ and $S_{1 i}=\sum_{j} w_{i j}^{2}$, where $\mathrm{j} \neq \mathrm{i}$ and $S_{1 i}^{*}=\sum_{j} w_{i j}^{2}$ where $\mathrm{j}=\mathrm{i}$, $\bar{x}$ and $\mathrm{s}^{2}$ represent the mean and diffraction of the sample, respectively. The standardized $\mathrm{G}$ and $\mathrm{G} *$ values are interpreted based on the Z-score table. The $\mathrm{G} *$ index was used in this study (Ord \& Gates, 1995). Spatial autocorrelation analysis can reveal the correlation between a certain regional unit in terms of common geographic features or attribute values (Syed et al, 2004; Diouf and Lambin, 2001) and can be analyzed from global and local perspectives. The commonly used spatial autocorrelation measure indexes are Moran's I value and Local indication of spatial association (LISA) value. Global Moran's I can reveal the global spatial correlation of vegetation coverage. Local Moran's I index can reveal the local spatial aggregation characteristics of vegetation coverage in the case study. Its essence is that the index is high, indicating similar spatial unit aggregation; otherwise, it indicates different spatial unit aggregation (Jian et al, 2015; Jiang et al, 2014). This analysis evaluates the pattern of distribution in space with simultaneous consideration of locations and features. The analysis results show whether the effects have random, dispersed, or clustered distribution in space. The tool calculates the Moran's index and evaluates the 
significance of the calculated index using the standard scores of $\mathrm{Z}$ and $\mathrm{P}$ values. Table 2 according to significance levels classified z score and $\mathrm{p}$-value. The Moran's index for spatial autocorrelation is calculated as follows (Anselin, 1995):

$$
I_{i}=\frac{x_{i}-\bar{x}}{s_{i}^{2}} \sum_{j=1, j \neq 1}^{n} w_{i, j} w_{i, j}\left(x_{i}-\bar{x}\right)
$$

Where $\mathrm{x}_{\mathrm{i}}$ is the amount of precipitation on the cell $\mathrm{i}, \mathrm{x}$ is the mean rainfall on the cell, and the cells are adjacent to the cell $\mathrm{d}$.

Table 2 Critical z-scores, p-values, and significance levels.

\begin{tabular}{|c|c|c|}
\hline z-score & p-value & Confidence level \\
\hline z-score $<-1.65$ or z-score $>+1.65$ & $<0.10$ & $90 \%$ \\
\hline z-score $<-1.96$ or z-score $>+1.96$ & $<0.05$ & $95 \%$ \\
\hline z-score $<-2.58$ or z-score $>+2.58$ & $<0.01$ & $99 \%$ \\
\hline
\end{tabular}

In this study, distance (d) was considered $14 \mathrm{~km}$, and $\mathrm{w}_{\mathrm{i}, \mathrm{j}}$ is the cell's spatial weight between $\mathrm{i}$ and $\mathrm{j}$. Also, $s_{i}^{2}$ is calculated using the equation (8):

$$
S_{i}^{2}=\frac{\sum_{j=1 j \neq i}^{n} w_{i . j}}{n-1}-\bar{X}^{2}
$$

Where $\mathrm{n}$ is equal to the number of cells in the interval $\mathrm{d}$. The standard $\mathrm{z}_{\mathrm{Ii}}$ score is obtained using the equation (9):

$$
z_{I i}=\frac{I_{i}}{\sqrt{V}\left[I_{i}\right]}
$$

In the above equation, $\mathrm{V}\left[\mathrm{I}_{\mathrm{i}}\right]$ is calculated using the following equation:

$$
E[I]=-\frac{\sum_{j=1}^{n} j \neq i}{n-1} \quad V[I]=E\left[I_{1}^{2}\right]-E\left[I_{1}^{2}\right]
$$

\section{Results}

In the first, Geometric corrections and necessary radiometric and atmospheric corrections were applied to the corresponding images, and then the indices' time series were generated, as shown in Figure 2. 


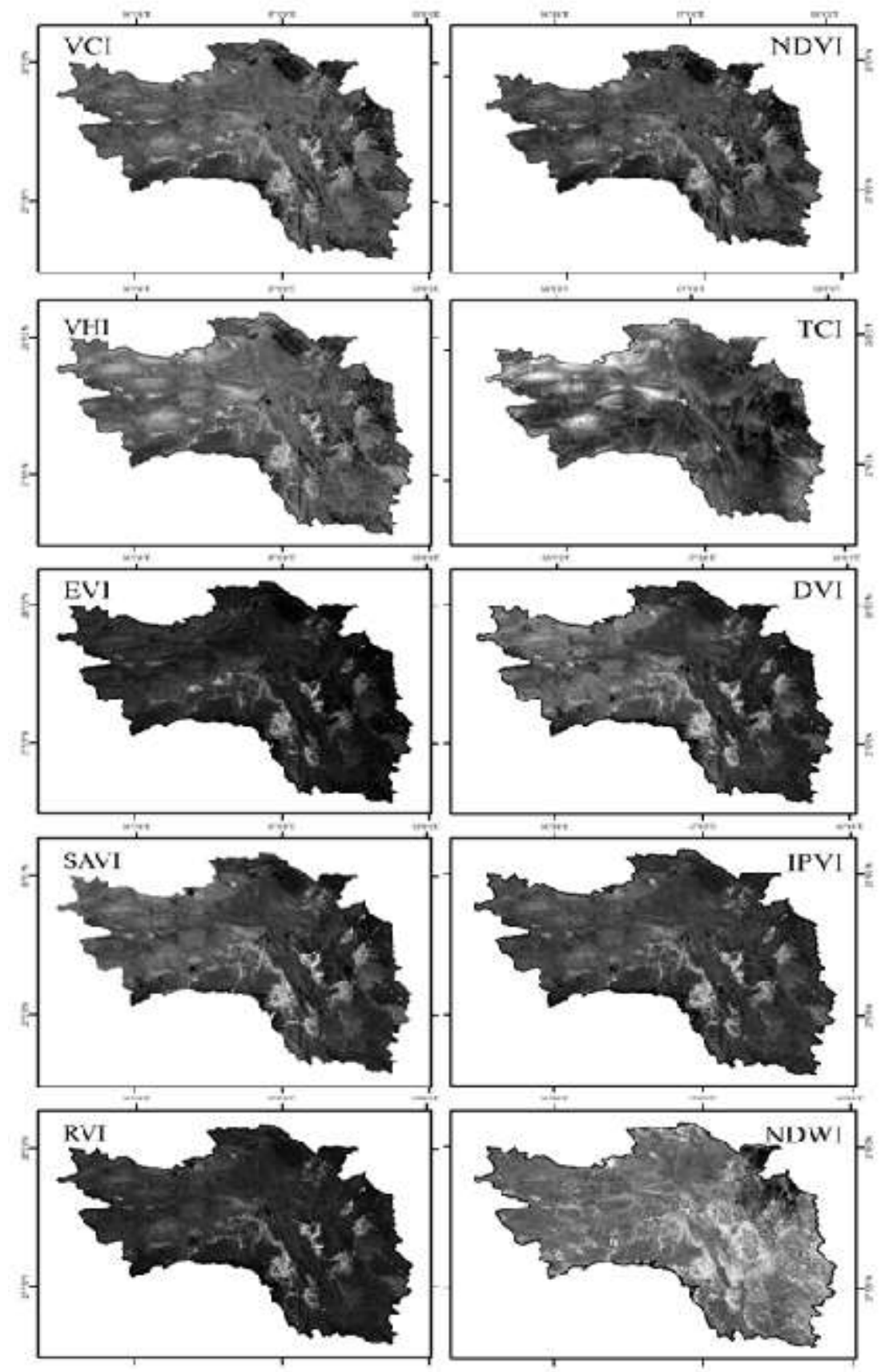

Fig 2: The vegetation indices in the study area

The results of how the correlation between precipitation and the vegetation indices is spatially distributed shown in figure 3. According to these results, Precipitation was poorly correlated with the vegetation indices DVI and EVI, except for a limited range elsewhere. For example, the correlation coefficient between precipitation and the vegetation index DVI was between 0.26 and 0.36 in $17.7 \%$ of the study area (Table 3). A survey of precipitation variability with the EVI indicated that $27 \%$ of the study area, comprising mainly the east and small parts of the southwest, had a correlation coefficient between 0.28 and 0.38 . The spatial variability of precipitation with the vegetation index IPVI showed that unlike the vegetation indices DVI and EVI that had the highest relationship with precipitation in the eastern and southern regions of the study area, the vegetation index IPVI had the highest relationship with precipitation in the northern. In this index, about $57 \%$ of the study area had a correlation coefficient between 0.2 and 0.4 . Moreover, $19.5 \%$ of the study area, covering mainly the northern region, had a correlation coefficient between 0.4 and 0.5 (Table 3). In the vegetation index NDVI, the coefficient of interchangeability of precipitation with this index was weak in all regions of the study area, except in the southeast. 

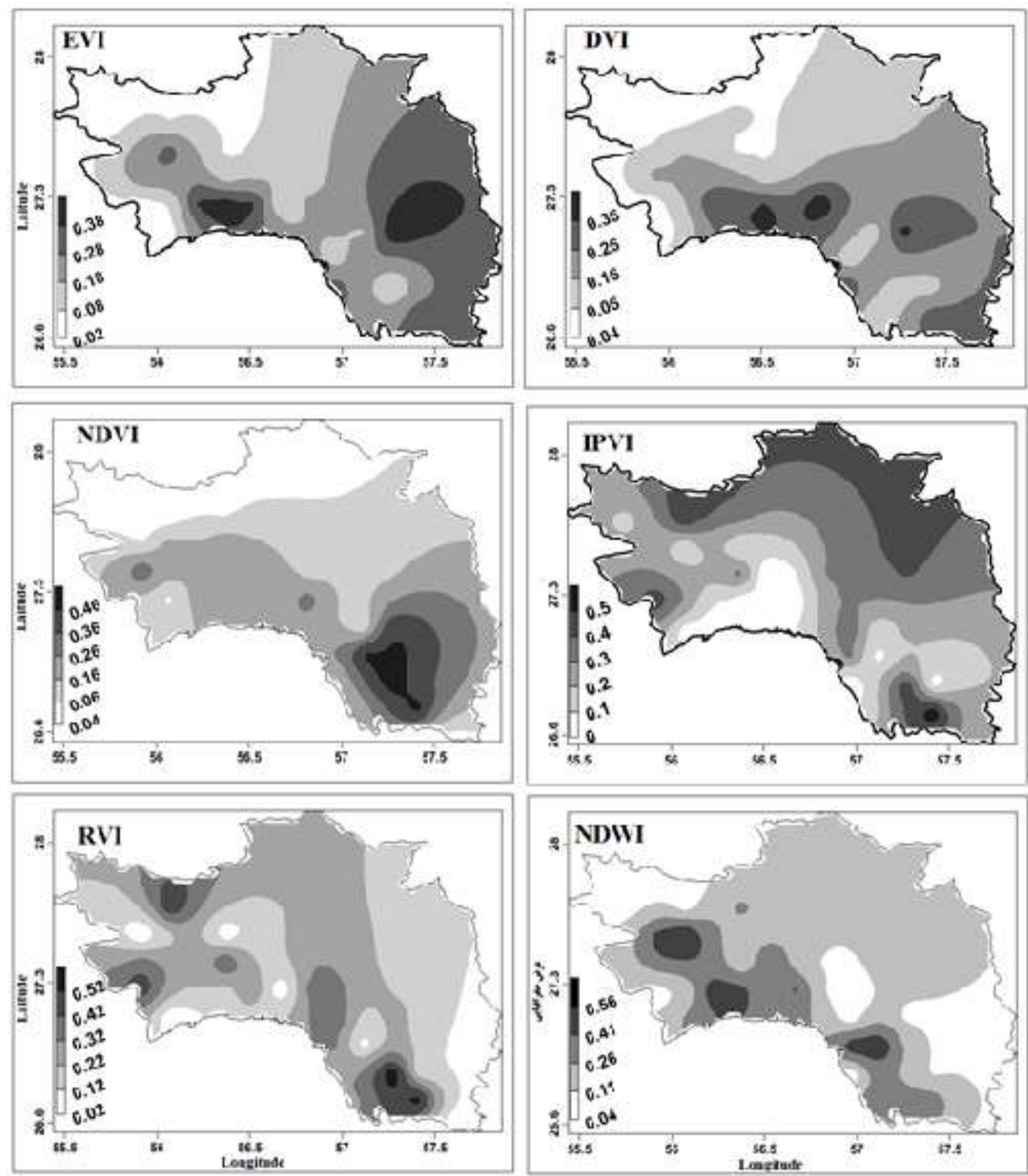

Fig 3: The spatial distribution of the correlation between precipitation and the vegetation indices

In the vegetation index NDVI, most of the study area had a correlation coefficient between 0.1 to 0.16 . The spatial variability of precipitation with the vegetation index NDWI was approximately similar to that with the vegetation index DVI, with the difference that the coefficient of precipitation variability was higher with the vegetation index NDWI than with the other index. The range of variability of precipitation with this index was from 0.1 to 0.56 (Fig 3). However, in the vegetation index NDWI, most of the area (59.2\%), which covers mainly the Northern half of the study area, had a correlation coefficient between 0.11 and 0.26 . The spatial distribution of the correlation between precipitation and the RVI index indicated that the spatial variability of precipitation with this index was mainly related to the southeast and west of the study area. In this index, $40.4 \%$ of the study area had a coefficient between 0.22 and 0.32 , while only $3.9 \%$ of the study area had a correlation coefficient above 0.42 (Table 3 ).

Table 3: Classes of the correlation coefficient between precipitation and the vegetation indices

\begin{tabular}{|c|c|c|c|c|c|}
\hline indeice & class & Percentage & indeice & class & Percentage \\
\hline \multirow[t]{5}{*}{ IPVI } & $0-0.1$ & 7 & \multirow[t]{5}{*}{ RVI } & $0.02-0.12$ & 8.9 \\
\hline & $0.1-0.2$ & 15.1 & & $0.12-0.22$ & 36.1 \\
\hline & $0.2-0.3$ & 29.8 & & $0.22-0.32$ & 40.4 \\
\hline & $0.3-0.4$ & 28.5 & & $0.32-0.42$ & 10.7 \\
\hline & $0.4-0.5$ & 19.5 & & $0.42<$ & 3.9 \\
\hline \multirow[t]{3}{*}{ EVI } & $0.02-08$ & 10 & \multirow[t]{3}{*}{ NDWI } & $0.04-0.11$ & 18.4 \\
\hline & $0.08-0.18$ & 28.2 & & $0.11-0.26$ & 59.2 \\
\hline & $0.18-0.28$ & 28.5 & & $0.26-0.41$ & 17.6 \\
\hline
\end{tabular}




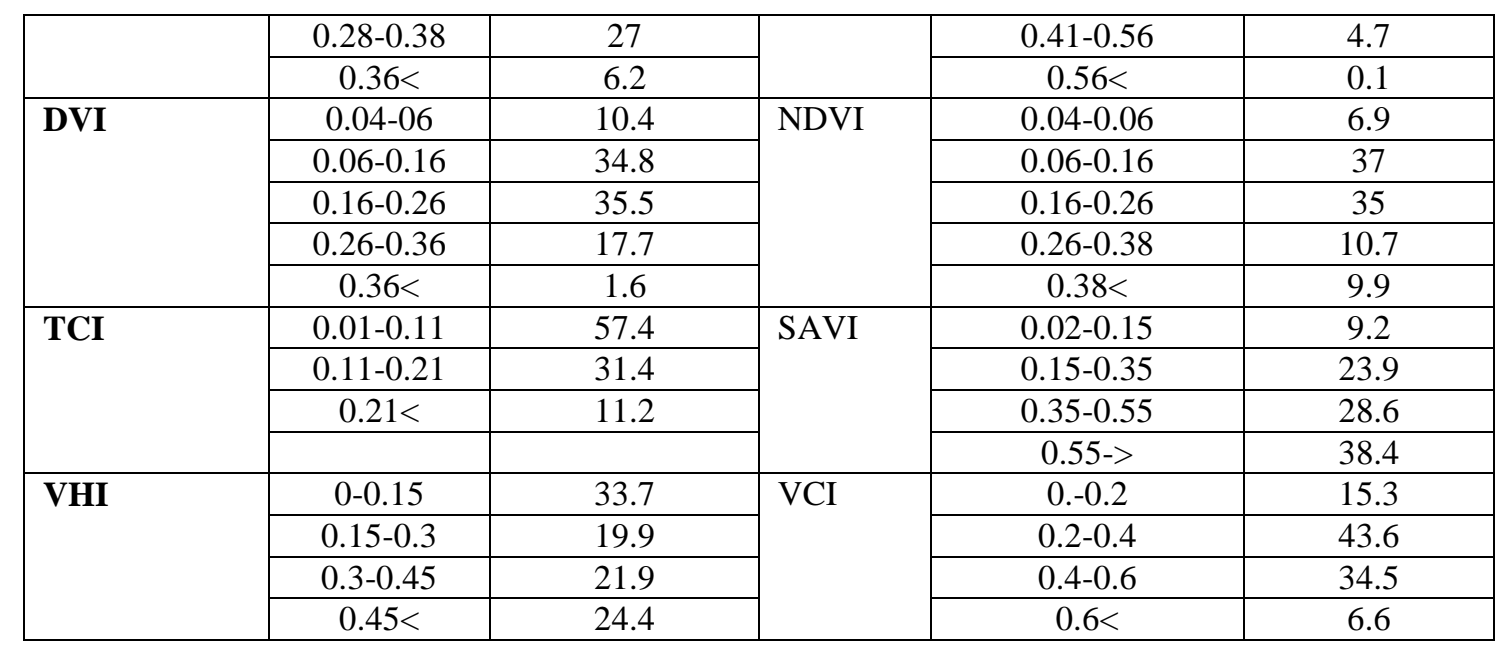

Among the vegetation indices, SAVI had the highest correlation coefficient with precipitation. In this index, $38.4 \%$ of the study area, mainly covering the northern region, experienced a correlation coefficient above 0.55 . Moreover, $28.6 \%$ of the study area had a correlation coefficient between 0.35 and 0.55 . However, TCI among the vegetation indices had the lowest correlation coefficient with precipitation, which had the highest correlation coefficient with 0.21 in the south of the study area. Following SAVI, VCI experienced the highest coefficient of variability with precipitation. In this index, $34.5 \%$ of the study area, mainly covering the eastern region, had a positive correlation coefficient from 0.4 to 6.6. At this point, only small spots in the eastern region of the study area had a correlation coefficient of 0.6. The variability of precipitation with the vegetation index VHI was almost similar to that with the vegetation index VCI, except that the correlation coefficient was reduced in VHI.
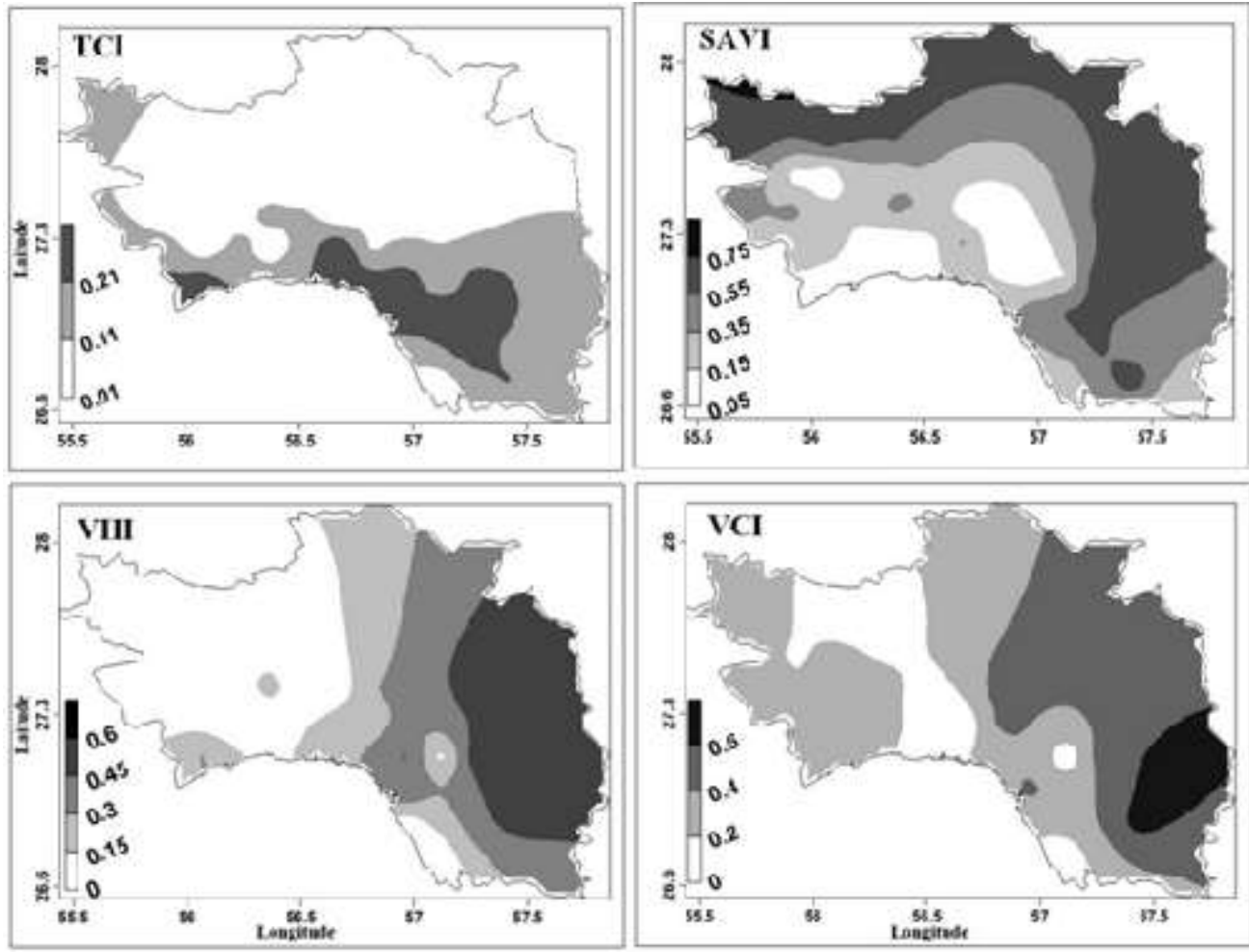

Continued from Fig 3: The spatial distribution of the correlation between precipitation and the vegetation indices

The spatial autocorrelation model with the indices based on the spatial indices GI * and I are given in Figure 4 to investigate more precisely the relationship between precipitation and the vegetation indices. The spatial pattern between precipitation and DVI was investigated. It was observed that based on both GI * and I indices, precipitation and DVI had a positive spatial autocorrelation pattern (table 5) in the eastern and southern regions of the study area. It was also realized that precipitation and DVI had a negative spatial autocorrelation pattern in the western and northern regions of the study area. This situation indicated that 
DVI was mainly affected by precipitation in the southern region of the province. However, according to the GI * index, approximately $19 \%$ of the study area had a positive spatial autocorrelation pattern with DVI. However, $44.36 \%$ of the study area had a random pattern (Table 4 ).

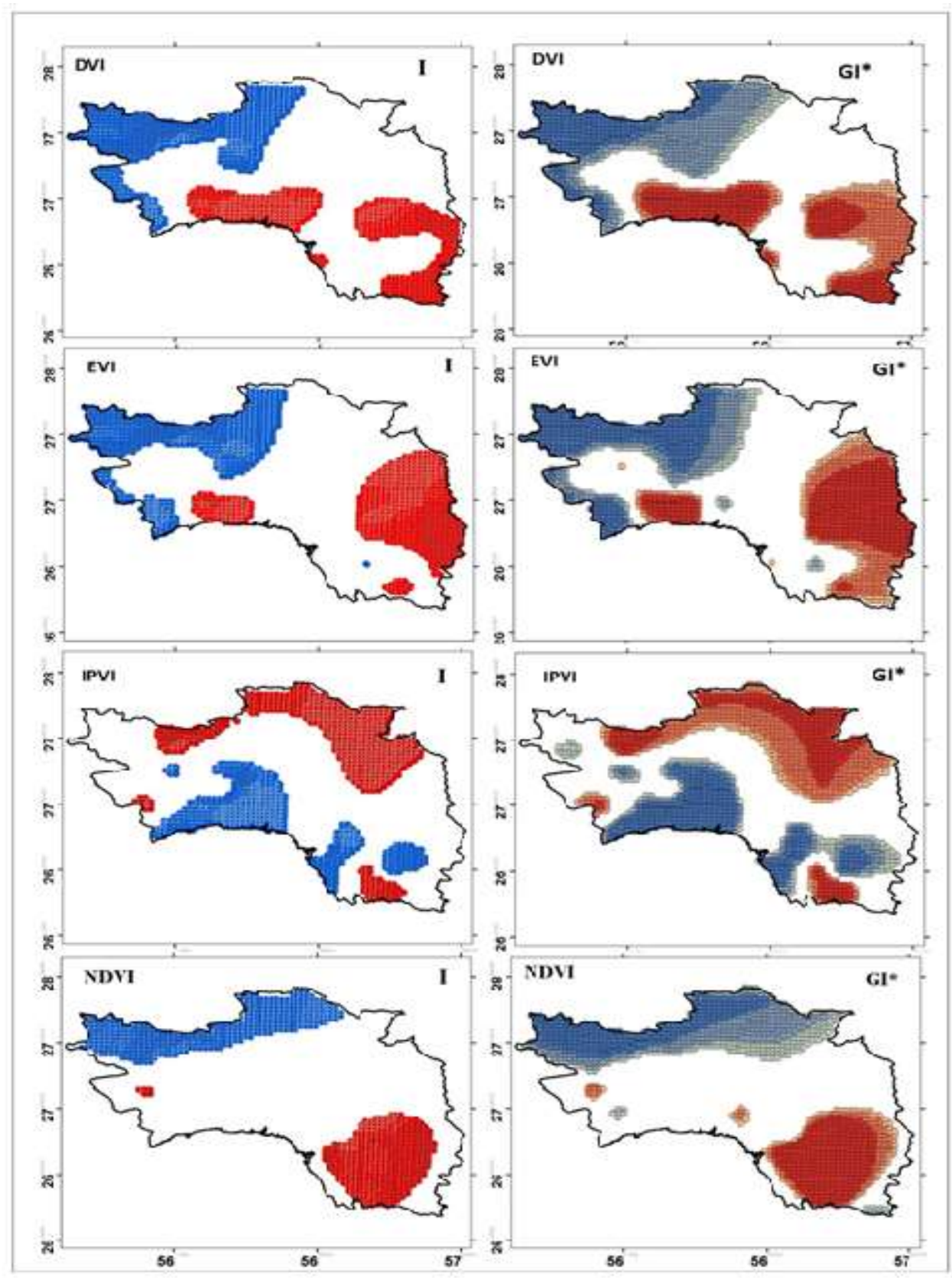

Fig 4: The spatial distribution of the spatial pattern of precipitation with the vegetation indices

The spatial autocorrelation with EVI based on the GI* and I indices were almost similar to that with DVI (table 5). However, in this index, the positive autocorrelation pattern was mainly observed in the eastern region of the study area and only had a small cluster pattern in the southern region of the study area. The high cluster pattern based on the I index had a positive spatial autocorrelation pattern in approximately $12.954 \%$ of the study area. However, according to the GI * index, approximately $14 \%$ of the study area formed a high cluster pattern. Therefore, the identification of the high cluster pattern may differ in terms of the percentage of coverage. However, these two indices had minimal differences in terms of location. The reason is that in the GI* index, distribution patterns were examined at three levels of $99 \%$, 95\%, and $90 \%$, and thus, they may differ in terms of the extent covered by the positive spatial autocorrelation pattern. Unlike the vegetation indices DVI and EVI, precipitation and IPVI had a positive spatial autocorrelation pattern in the northern region of the study area. Conversely, precipitation and IPVI had a negative spatial autocorrelation pattern in the southern region and parts of the southeast region of the study area. The positive spatial autocorrelation based on the GI * and I indices was $30.16 \%$ and $20.791 \%$, respectively. 
However, the low-cluster pattern between IPVI and precipitation based on the GI *and I indices was $23.52 \%$ and $18.204 \%$, respectively. The effects of the spatial pattern of precipitation with NDVI as the core were observed more in the eastern region of the study area. The spatial autocorrelation between precipitation and NDVI based on the GI* and I indices had a positive spatial autocorrelation pattern in $12.25 \%$ and $10.22 \%$ of the study area, respectively. However, $33.53 \%$ and $20.64 \%$ of the study area, mainly covering the northern region, had a negative spatial autocorrelation pattern based on the GI* and I indices, respectively.

The distribution of the spatial autocorrelation pattern of precipitation with NDWI in terms of positive cluster pattern experienced a similar situation to the DVI index (table 5). However, the positive autocorrelation pattern of precipitation with NDWI was observed only in the southern and western regions of the study area. Based on the GI* and I indices, the positive spatial autocorrelation pattern covered $26.26 \%$ and $22.69 \%$ of the study area, respectively, However, the negative spatial autocorrelation pattern only covered $13.03 \%$ and $8.98 \%$ of the northwest and southeast regions in the study area based on the GI* and I indices, respectively (Fig 4). Among the vegetation indices, the positive spatial autocorrelation pattern of precipitation with RVI had a more scattered distribution. Small nuclei spread throughout the study area according to the GI* and I indices.

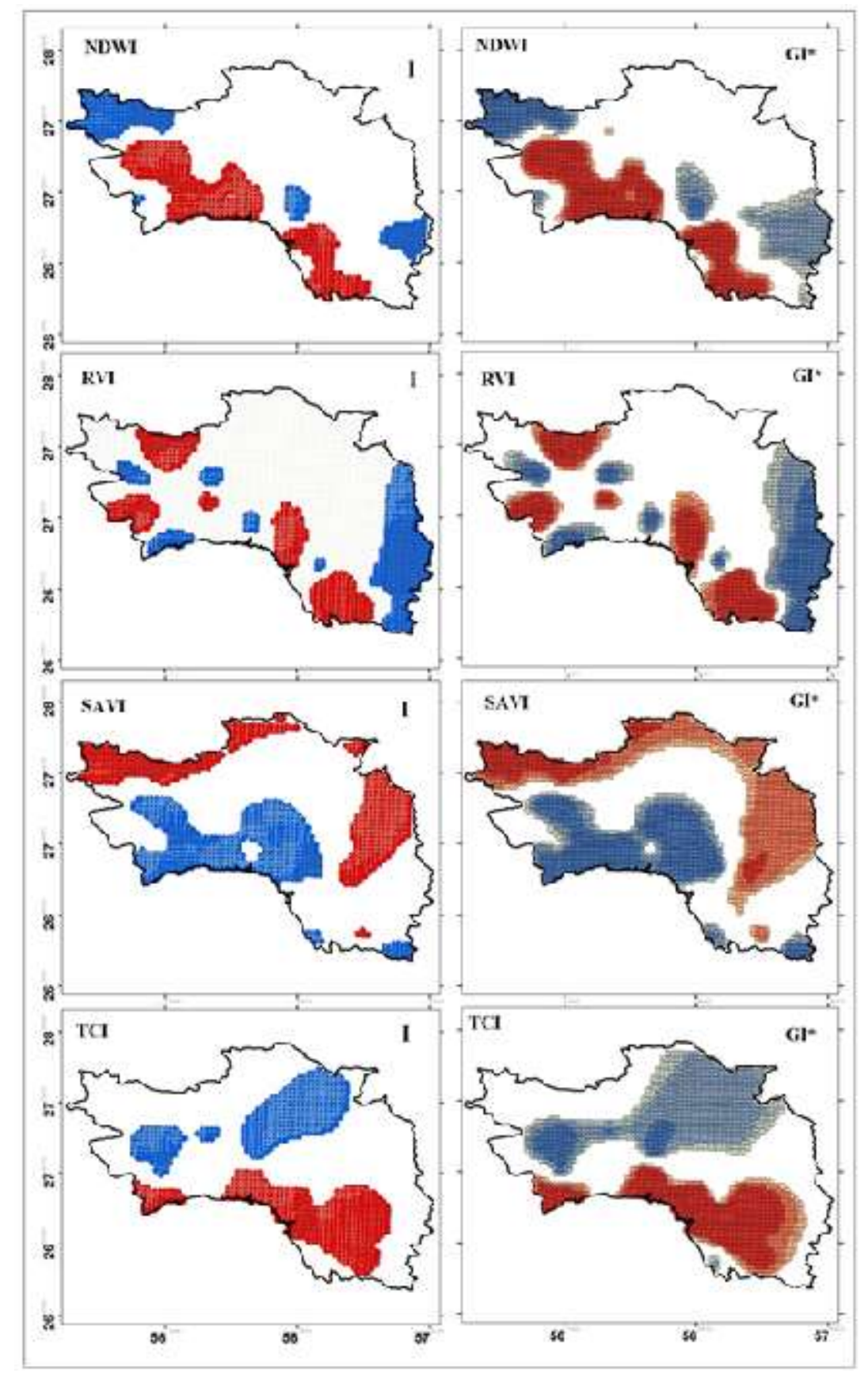

Continued from Fig 4: The distribution of the spatial precipitation pattern with the vegetation indices 
The spatial distribution of the spatial autocorrelation pattern of precipitation with SAVI experienced a similar situation to the IPVI index, although the range of the positive spatial autocorrelation pattern was narrower. For example, based on the GI* and I indices, the spatial autocorrelation pattern of precipitation with SAVI was $22.35 \%$ and $11.66 \%$, while it was $32.4 \%$ and $25.96 \%$ for the negative spatial autocorrelation pattern, respectively. Precipitation and TCI, like most other indices, had a high cluster pattern in the southern region of the study area, but a low cluster pattern in the northern and central regions of the study area.

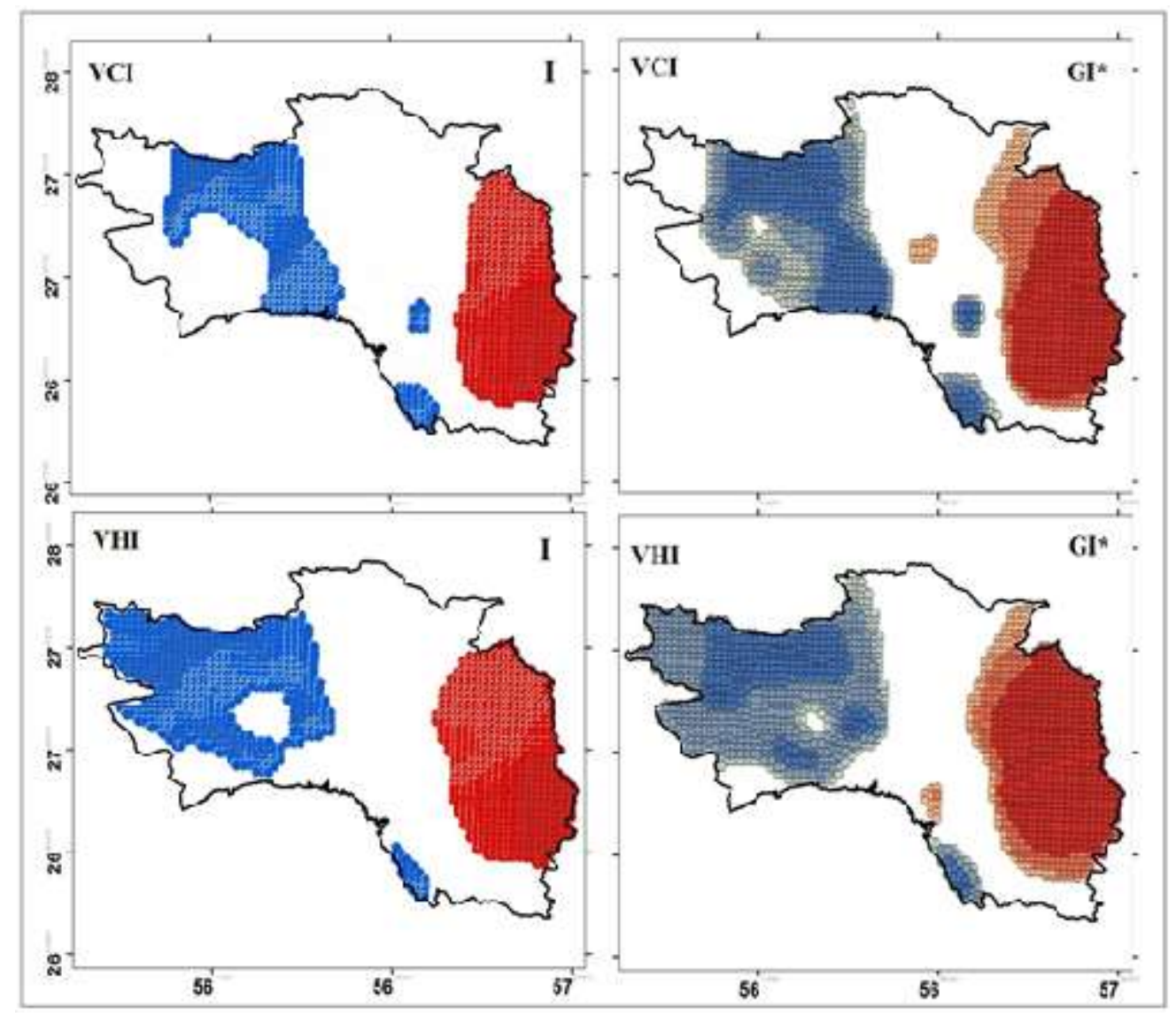

Continued from Fig 4: The distribution of the spatial precipitation pattern with the vegetation indices

The spatial autocorrelation pattern of precipitation with VCI and VHI based on the GI* and I indices experienced a similar situation. The positive spatial autocorrelation pattern in both indices was related to the eastern region of the study area, while the negative spatial autocorrelation pattern formed more in the western region of the study area. However, VCI and VHI based on the GI* and I indices had the lowest positive spatial autocorrelation pattern among the vegetation indices, respectively. For example, the positive spatial autocorrelation pattern based on the GI* and I indices was $7.47 \%$ and $6.391 \%$ for VCI, and $9.37 \%$ and $6.538 \%$ for VHI, respectively (Fig 4).

Table 4: Percentage covered by the spatial autocorrelation pattern of precipitation with the vegetation indices based on the $\mathrm{GI}^{*}$ index

\begin{tabular}{|l|r|r|r|r|r|}
\hline \multicolumn{1}{|c|}{ Pattern } & \multicolumn{1}{|c|}{ DVI } & \multicolumn{1}{c|}{ EVI } & \multicolumn{1}{c|}{ IPVI } & \multicolumn{1}{c|}{ NDVI } & NDWI \\
\hline Negative spatial autocorrelation pattern 99\% & 13.08 & 18.40 & 15.13 & 12.69 & 6.73 \\
\hline Negative spatial autocorrelation pattern 95\% & 17.57 & 9.86 & 4.49 & 12.59 & 3.47 \\
\hline Negative spatial autocorrelation pattern 90\% & 5.71 & 5.12 & 3.90 & 8.25 & 2.83 \\
\hline No pattern & 44.36 & 52.73 & 46.32 & 54.22 & 60.71 \\
\hline Positive spatial autocorrelation pattern 90\% & 0.44 & 0.24 & 0.63 & 0.20 & 0.54 \\
\hline Positive spatial autocorrelation pattern 95\% & 3.37 & 8.49 & 8.74 & 2.05 & 2.78 \\
\hline Positive spatial autocorrelation pattern 99\% & 15.47 & 6.15 & 20.79 & 10.00 & 22.94 \\
\hline \multicolumn{1}{|c|}{ Pattern } & RVI & Savi & TCI & VCI & VHI \\
\hline Negative spatial autocorrelation pattern 99\% & 5.12 & 20.74 & 4.64 & 16.94 & 12.84 \\
\hline Negative spatial autocorrelation pattern 95\% & 3.12 & 8.05 & 23.18 & 10.44 & 24.45 \\
\hline
\end{tabular}




\begin{tabular}{|l|r|r|r|r|r|}
\hline Negative spatial autocorrelation pattern 90\% & 2.54 & 3.61 & 7.03 & 8.15 & 6.34 \\
\hline No pattern & 66.23 & 45.24 & 44.66 & 57.00 & 47.00 \\
\hline Positive spatial autocorrelation pattern 90\% & 0.68 & 0.83 & 0.20 & 0.93 & 0.73 \\
\hline Positive spatial autocorrelation pattern 95\% & 4.64 & 10.15 & 3.56 & 4.10 & 5.81 \\
\hline Positive spatial autocorrelation pattern 99\% & 17.67 & 11.37 & 16.74 & 2.44 & 2.83 \\
\hline
\end{tabular}

Table 5: Percentage covered by the spatial autocorrelation pattern of precipitation with the vegetation indices based on the GI* and I indices

\begin{tabular}{|l|c|c|c|c|}
\hline \multirow{2}{*}{ INDEX } & \multicolumn{2}{|c|}{$\begin{array}{c}\text { Positive spatial autocorrelation pattern } \\
\mathbf{9 5 \%}\end{array}$} & $\begin{array}{c}\text { Negative spatial autocorrelation } \\
\text { pattern 95\% }\end{array}$ \\
\cline { 2 - 5 } & $\mathrm{I}$ & $\mathrm{GI}^{*}$ & $\mathrm{I}$ & $\mathrm{GI}^{*}$ \\
\hline DVI & 15.569 & 19.28 & 25.72 & 36.36 \\
\hline EVI & 12.954 & 14.88 & 24.793 & 33.38 \\
\hline IPVI & 20.791 & 30.16 & 18.204 & 23.52 \\
\hline NDVI & 10.102 & 12.25 & 20.644 & 33.53 \\
\hline NDWI & 22.694 & 26.26 & 8.98 & 13.03 \\
\hline RVI & 14.765 & 18.99 & 7.979 & 10.78 \\
\hline SAVI & 11.664 & 22.35 & 25.964 & 32.4 \\
\hline TCI & 16.886 & 20.5 & 19.082 & 34.85 \\
\hline VCI & 6.391 & 7.47 & 22.255 & 35.53 \\
\hline VHI & 6.538 & 9.37 & 30.649 & 43.63 \\
\hline
\end{tabular}

\section{Conclusion}

In the present study, we used precipitation data from 30 rain gauge stations and vegetation indices DVI, EVI, IPVI, NDVI, NDWI, RVI, SAVI, TCI, VCI, and VHI derived from Landsat TM, ETM +, and OLI satellite data over 20 years from 1997 to 2017. The aim was to investigate the spatial autocorrelation pattern of precipitation with the vegetation indices in the Bandar Abbas sub-basin. The study's results showed that precipitation was directly and significantly correlated with most of the vegetation indices. It means that with increasing rainfall, vegetation increases and vice versa. This finding is consistent with the study of Mackerem et al. (1986), showing that vegetation indices in most cases (more than 90\%) were significantly related to precipitation and temperature. Also, other researchers in their studies noted a high correlation between the vegetation index and precipitation (Young et al., 1998; Jei \& Peter, 2004; Li et al., 2004), which further confirms the present study's findings. However, among the studied indices, the highest variability of precipitation was related to NDWI, RVI, Savi, and VCI, and, on the contrary, TCI had the least variability with precipitation. The GI* and I indices were used to investigate the relationship between precipitation and the vegetation indices more accurately. The results of the GI* and I indices showed that the spatial relationship between precipitation and the vegetation indices in most of the study area, especially in the southern and eastern parts of the study area, had a positive spatial autocorrelation pattern. As a result, vegetation in the study area's southern and eastern regions is more affected by precipitation based on the GI* and I indices. Among these indices, NDWI and IPVI had the highest spatial pattern these results are consistent with the findings Abdulhafedh (2017). Therefore, it can be concluded that climatic elements, especially precipitation, have a significant impact on vegetation status. Thus, the vegetation disappears rapidly by decreasing precipitation. Overall, based on the results, it can be mentioned that about $30-40 \%$ of vegetation is related to precipitation changes, and other vegetation changes can be related to factors, such as micro-precipitation, drought, and cold, as well as human factors such as land use change and grazing.

\section{References}

1. Azizi G., Miri M., Mohamadi H., Pourhashemi M. (2015): Analysis of relationship between forest decline and precipitation changes in Ilam province. Iranian Journal of Forest and Poplar Research, 23: 502-515. (In Persian)

2. Ahl, D.E.; Gower, S.T.; Burrows, S.N.; Shabanov, N.V.; Myneni, R.B.; Knyazikhin, Y. (2006). Monitoring spring canopy phenology of a deciduous broadleaf forest using MODIS. Remote Sens. Environ. 2006, 104, 88-95. [CrossRef] 
3. Abdulhafedh, A. (2017) A Novel Hybrid Method for Measuring the Spatial Autocorrelation of Vehicular Crashes: Combining Moran's Index and Getis-Ord* Gi Statistic. Open Journal of Civil Engineering, 7, 208-221. https://doi.org/10.4236/ojce.2017.72013

4. Anselin, L. (1995). Local Indicators of Spatial Association LISA, Geographical Analysis, 27, 93115.

5. Bing, G.; Yi, Z.; Shi-Xin, W.; He-Ping, T. The relationship between normalized difference vegetation index (NDVI) and climate factors in the semiarid region: A case study in Yalu Tsangpo River basin of Qinghai-Tibet Plateau. J. Mt. Sci. 2014, 11, 926-940

6. Boles, S.H.; Xiao, X.; Liu, J.; Zhang, Q.; Munkhtuya, S.; Chen, S.; Ojima, D. (2004). Land cover characterization of Temperate East Asia using multi-temporal VEGETATION sensor data. Remote Sens. Environ. 2004, 90, 477-489. [CrossRef]

7. Carvalho, F. M. V.; Ferreira, L. G.; Lobo, F. C.; Diniz-filho, A. F.; Bini, L.M. (2008). Padrões de autocorrelação espacial de índices de vegetação MODIS no bioma cerrado. Revista Árvore, ViçosaMG, v.32, n.2, p.279-290

8. Ceccato, P.; Flasse, S.; Grégoire, J.-M. (2002). Designing a spectral index to estimate vegetation water content from remote sensing data: Part 2. Validation and applications. Remote Sens. Environ. 2002, 82, 198-207. [CrossRef]

9. Ding, W.R. (2016). Temporal and spatial Evolution characteristics of vegetation NDVI and its Driving Factors in Karst Area of Southeast Yunnan, China. Res. Soil Water Conserv. 2016, 23, 227231.

10. Diouf, A.; Lambin, E.F. (2001). Monitoring land-cover changes in semi-arid regions: Remote sensing data and field observations in the Ferlo, Senegal. J. Arid Environ. 2001, 48, 129-148. [CrossRef]

11. Fischer, M.M. Wang, J. (2011) Spatial Data Analysis: Models, Methods, and Techniques. Springer, New York. https://doi.org/10.1007/978-3-642-21720-3

12. Fensholt, R.; Sandholt, I. (2003). Derivation of a Shortwave Infrared Water Stress Index From MODIS Near- and Shortwave Infrared Data in a Semiarid Environment. Remote Sens. Environ. 2003, 87, 111-121. [CrossRef]

13. Ghavidel, M., Bayat, P., Farashia, M.E. (2021). Satellite image processing of the Buxus hyrcana Pojark dieback in the Northern Forests of Iran. Journal of Forest Science, 67, 2021 (2): 71-79

14. Gao, B.-C. (1996). NDWI-A normalized difference water index for remote sensing of vegetation liquid water from space. Remote Sens. Environ. 1996, 58, 257-266. [CrossRef]

15. Gu, Y.; Brown, J.F.; Verdin, J.P.; Wardlow, B. (2007). A five-year analysis of MODIS NDVI and NDWI for grassland drought assessment over the central Great Plains of the United States. Geophys. Res. Lett. 2007, 34, L06407. [CrossRef]

16. GISGeography (2019): What is NDVI (Normalized Difference Vegetation Index). Available at: https://gisgeography .com/ ndvi-normalized-difference-vegetation-index/

17. Houborg, R.; Soegaard, H.; Boegh, E. (2007). Combining vegetation index and model inversion methods for the extraction of key vegetation biophysical parameters using Terra and Aqua MODIS reflectance data. Remote Sens. Environ. 2007, 106, 39-58. [CrossRef]

18. Huete, A.R.; Jackson, R.D. (1988). Soil and atmosphere influences on the spectra of partial canopies. Remote Sens. Environ. 1988, 25, 89-105. [CrossRef]

19. Irons, J.R.; Dwyer, J.L.; Barsi, J.A. T (2012). The next Landsat satellite: The Landsat Data Continuity Mission. Remote Sens. Environ. 2012, 122, 11-21. [CrossRef]

20. Jian, P.; You, L.; Lu, T. (2015). Vegetation Dynamics and Associated Driving Forces in Eastern China during 1999-2008. Remote Sens. 2015, 7, 13641-13663. 
21. Jiang, W.G.; Yuan, L.H.; Wang, W.J. (2014). Spatio-temporal analysis of vegetation variation in the Yellow River Basin. Ecol. Indic. 2014, 51, 117-126. [CrossRef]

22. Jei, L., Peters, A.J. (2004). A Spatial Regression Procedure for Evaluating the Relationship between AVHRR-NDVI and Climate in the Northern Great Plains, Int. J. Remote Sensing, 25, pp. 297-311.

23. Karimi, M., Shahedi, K., Raziei, T., Miryaghoubzadeh, M. (2020). Analysis of Performance of vegetation indices on agricultural drought using remote sensing technique in Karkheh basin. REMOTE SENSING \& GIS. 2020 [cited 2021June18];11(4):29-46. Available from: https://www.sid.ir/en/journal /ViewPaper .aspx ?id =761416

24. Kazeminia A. (2018): Application of remote sensing and GIS in the investigating vegetation coverage. Geospatial Engineering Journal, 9: 75-85

25. Lin, X.; Niu, J.; Berndtsson, R.; Yu, X.; Chen, X. (2020). NDVI Dynamics and Its Response to Climate Change and Reforestation in Northern China. Remote Sens. 2020, 12, 4138. [CrossRef]

26. Liu, Y.; Fu, B.J. (2013). Topographical variation of vegetation cover evolution and the impact of land use/cover change in the Loess Plateau. Arid Land Geogr. 2013, 36, 1097-1102

27. Li, J., Lewis, J., Rowland, J., Tappan, G. and L. L. Tieszen, (2004). Evaluation of Land Performance in Senegal Using Multi-temporal NDVI and Rainfall Series. Journal of Arid Environments, 59, pp. 463-480.

28. Maglione P., Parente C., Vallario A. (2013). Using WorldView-2 satellite imagery to support geoscience studies on Phlegraean area. American Journal of Geoscience, 3: 1-12.

29. Miura, T.; Huete, A.; Yoshioka, H. (2000). Evaluation of sensor calibration uncertainties on vegetation indices for MODIS. IEEE Trans. Geosci. Remote Sens. 2000, 38, 1399-1409. [CrossRef]

30. Mokarm, M., Mazin, M., Faraji, M., Mousavi, K. (2016). "Investigation of vegetation changes in different growing seasons using satellite imagery and its relation to temperature changes (study area: north of Darab city)." Iranian Natural Ecosystems, 8 (3), 1-20. [Persian]

31. Nagler, P.L.; Cleverly, J.; Glenn, E.; Lampkin, D.; Huete, A.; Wan, Z. (2005). Predicting riparian evapotranspiration from MODIS vegetation indices and meteorological data. Remote Sens. Environ. 2005, 94, 17-30. [CrossRef]

32. Naji T.A: (2018): Study of vegetation cover distribution using DVI, PVI, WDVI indices with 2Dspace plot. Journal of Physics Conference Series, 1003: 012083

33. Ord, J.K., and Geties, A. (1995).Local Spatial Autocorrelation Statistics: Distributional Issues and an Application, Geographical Analysis, 27(4), 286-306.

34. Robinson N.P., Allred B.W., Jones M.O., Moreno A., Kumball J.S., Naugle D.E., Erickson T.A., Richardson A.D. (2017): A dynamic Landsat derived normalized difference vegetation index (NDVI) product for the conterminous United States. Remote Sensing, 9: 863.

35. Sims, D.A.; Rahman, A.F.; Cordova, V.D.; El-Masri, B.Z.; Baldocchi, D.D.; Bolstad, P.V.; Flanagan, L.B.; Goldstein, A.H.; Hollinger, D.Y.; Misson, L. (2008). A new model of gross primary productivity for North American ecosystems based solely on the enhanced vegetation index and land surface temperature from MODIS. Remote Sens. Environ. 2008, 112, 1633-1646. [CrossRef]

36. Syed, S.S.; Imran, A.S. (2004). Spatial pattern analysis of seeds of an arable soil seed bank and its relationship with above-ground vegetation in an arid region. J. Arid Environ. 2004, 3, 311-327.

37. Safari A., Sohrabi H., Powell S. (2018). Comparison of satellite-based estimates of aboveground biomass in coppice oak forests using parametric, semiparametric, and nonparametric modeling methods. Journal of Applied Remote Sensing, 12: 046026.

38. Solano, R.; Didan, K.; Jacobson, A.(2012). Huete, A. MODIS Vegetation Index User's Guide. Version 2.00, May 2010; Collection 5. Available online: http://vip.arizona.edu /documents/MODIS /MODIS_VI_UsersGuide_01_2012.pdf (accessed on 6 June 2018). 
39. Thiele J.C., Nuske R.S., Ahrends B., Panferov O., Albert M., Staupendahl K., Junghans U., Jansen M., Saborowski J. (2017). Climate change impact assessment - a simulation experiment with Norway spruce for a forest district in Central Europe. Ecological Modelling, 346: 30-47.

40. United States Geological Survey-USGS. (2019). Available online: https://www.usgs.gov/landresources /nli/ landsat (accessed on 1 July 2019).

41. Virgílio A. Bento, V.A., Trigo, I.F., Gouveia, C.M., DaCamara, C.C. (2018). Contribution of Land Surface Temperature (TCI) to Vegetation Health Index: A Comparative Study Using Clear Sky and All-Weather Climate Data Records. Remote Sens. 2018, 10, 1324; doi:10.3390/rs10091324

42. Vani V., Mandla V.R. (2017). Comparative study of NDVI and SAVI vegetation indices in Anantapur district semiarid areas. International Journal of Civil Engineering \& Technology, 8: 287 300 .

43. Wardlow, B.D.; Egbert, S.L.; Kastens, J.H. (2007). Analysis of time-series MODIS 250 m vegetation index data for crop classification in the U.S. Central Great Plains. Remote Sens. Environ. 2007, 108, 290-310. [CrossRef]

44. Waring, R.H.; Coops, N.C.; Fan, W.; Nightingale, J.M. (2006). MODIS enhanced vegetation index predicts tree species richness across forested ecoregions in the contiguous USA. Remote Sens. Environ. 2006, 103, 218-226. [CrossRef]

45. Xiao, X.; Hagen, S.; Zhang, Q.; Keller, M.; Moore, B. (2006). Detecting leaf phenology of seasonally moist tropical forests in South America with multi-temporal MODIS images. Remote Sens. Environ. 2006, 103, 465-473. [CrossRef]

46. Yengoh, G.T.; Dent, D.; Olsson, L.; Tengberg, A.E.; Iii, C.J.T. (2015). Use of the Normalized Difference Vegetation Index (NDVI) to Assess Land Degradation at Multiple Scales: Current Status, Future Trends, and Practical Considerations. Springer Brief Environ. Sci. 2015, 100

47. Yang, L., Wylie, B., Tieszen, L. L., and B. C., Reed. (1998). An analysis of Relationships Among Climate Forcing and Time-integrated NDVI of Grasslands over the U.S. Northern and Central Great Plains, Remote Sens. Environ, 65, pp. 25-37. 